Актуальні проблеми розвитку економіки регіону. Вип 16. T.2

4. Kucherenko, Y.A. "Features of investment activities of agricultural enterprises." Investments: practice and experience, no.7, 2018, pp. 82-85, www.investplan.com.ua/?op=1\&z=602- Same 3 \& i = 15. Accessed 2 Nov. 2020.

5. Buffett, W. Essays on investment, corporate finance and corporate governance. Moscow, Alpina Business Books, 2005.

6. Yastrebov, Y.Y. "Development of a strategy for allocating financial resources of agricultural enterprises in the context of internationalization of the economy." Agrosvit, no.20, 2018, pp. 43-47. Vernadsky National Library, nbuv.gov.ua/UJRN/agrosvit_2018_20_8. Accessed 2 Nov. 2020.

7. Kameneva, T. "Investment service or what is really the investment attractiveness of Ukraine." Public opinion on lawmaking, no.13, 2020, pp. 4-8. NBUVIAP, nbuviap.gov.ua/images/dumka/2020/13.pdf. Accessed 2 Nov. 2020.

8. Vitkovsky, Y. P. "Mobilization of sources of investment of agricultural producers and their investment attractiveness." Ukrainian Journal of Applied Economics, vol. 4, no. 4, 2019, pp. 395-401, ujae.org.ua/wp-content/uploads/2020/06/ujae_2019_r04_a44.pdf. Accessed 2 Nov. 2020.

9. Blank, I.O. Financial management. Kyiv: El'ga, 2004.

10. Vengurenko, T.G., and V.V.Plakhotnyuk. "Analysis of investment attractiveness of Ukraine." Business inform, no.4, 2020, pp. 103-111, www.business-inform.net. Accessed 2 Nov. 2020.

11. Kisil, M.I. "Investment potential of agriculture and its land component." Financial and credit mechanism of economic and social development: materials of the II International. scientific-practical internet conference (October 24-25, 2019). Kropyvnytskyi: Exclusive-Systems, 2019, pp. 66-69. KNTU, dspace.kntu.kr.ua/jspui/handle/123456789/9528. Accessed 2 Nov. 2020.

12. Coase, R. Firm, market and law. Moscow: New publishing house, 2007. library.fa, www.library.fa.ru/files/Coase.pdf. Accessed 2 Nov. 2020.

13. Bezditko, O.E. "Classification of risks of agricultural enterprises in order to select tools for their management.” Scientific horizons, no. 3, 2019, pp. 64-71. Vernadsky National Library, nbuv.gov.ua/UJRN/Vzhnau_2019_3_10. Accessed 2 Nov. 2020.

14. Tomchuk, O.F. "Methodical aspects of the analysis of loan capital of agricultural enterprises." Scientific Bulletin of Uzhhorod National University: Series: International Economic Relations and the World Economy, issue 27, 2019, pp. 76-83. Vernadsky National Library,nbuv.gov.ua/UJRN/Nvuumevcg_2019_27(2)_16. Accessed 2 Nov. 2020.

УДК 657:338.124

doi: 10.15330/apred.2.16.199-210

\title{
ОБЛІКОВА ІНФОРМАЦІЯ У СИСТЕМИ ФОРМУВАННЯ АНТИКРИЗОВОГО УПРАВЛІННЯ ПЕРСОНАЛОМ АГРАРНИХ ПІДПРИЕМСТВ
}

\author{
Львівський національний аграрний \\ університет, \\ Міністерство освіти і науки України, \\ кафедра обліку та оподаткування, \\ вул. В.Великого, 1, м.Львів \\ 80381, Україна, \\ тел.: 0973303771, \\ e-mail: Inau-oblik@ukr.net
}

\begin{abstract}
Анотація. Стаття спрямована на визначення методології формування системи антикризового управління персоналом аграрних підприємств. Досліджено методику аналізу обліку кадрів, їх тестування, виявленно професійно-кваліфікаційних характеристики, відповідності професійних навиків окремих працівників їхнім посадам 3 метою збільшення ефективності використання персоналу підприємства.

Крім того було обгрунтовано, що для сільського господарства, яке займає останні місця у питаннях впровадження прогресивних форм організації праці та управління виробничим
\end{abstract}


Актуальні проблеми розвитку економіки регіону. Вип 16. T.2

процесом, адаптація сучасного досвіду менеджменту, і особливо для управління людьми, сьогодні $є$ вкрай необхідним і актуальним. Одним із таких нових підходів $є$ перетворення працівників відділів кадрів на менеджерів по управлінню людськими ресурсами - HRменеджерами.

Визначено головні закономірності, позитивні, що сприяють досягненню цілей державної політики зайнятості і негативні, що перешкоджають їх досягненню. Автори відмітили, що тенденції процесів відтворення системи обліку робочих місць залишаються невизначеними закономірності і тенденції відтворення системи робочих місць вітчизняних підприємств та економіки загалом та не реалізуються резерви підвищення ефективності зайнятості за рахунок підвищення обгрунтованості державної політики сприяння створенню робочих місць та поширення моделей господарської поведінки, орієнтованих на розширене інтенсивне відтворення системи робочих місць

Встановлено, що антикризове управління персоналом $є$ важливою складовою управління підприємством і має значний вплив на ефективність його господарської діяльності.

Ключові слова: антикризове управління, облікова інформація, персонал, аграрне підприємство, робоче місце, фактори успіху.

\title{
Maletska O.I., Prokopyshyn O. S, Myronchuk Z.P. ACCOUNTING INFORMATION IN THE SYSTEM OF FORMATION OF ANTI- CRISIS MANAGEMENT OF PERSONNEL OF AGRICULTURAL ENTERPRISES
}

\author{
Lviv National Agrarian University, \\ Ministry of Education and Science of Ukraine, \\ Department of Accounting and Taxation \\ V.Velykoho Street1, Lviv \\ 79008, Ukraine \\ tel.: 0973303771, \\ e-mail: lnau-oblik@ukr.net
}

\begin{abstract}
The article is aimed at determining the methodology formation of the system crisis management personnel of agricultural enterprises. The method of personnel analysis, their testing, professional qualification characteristics, compliance professional skills individual employees with their positions in order to increase the efficiency the personnel of the enterprise are studied.

In addition, it was argued that for agriculture, which occupies the last place in the implementation of progressive forms labor organization and production process management, adaptation of modern management experience, and especially for people management, is extremely necessary and relevant today. One such new approach is the transformation of HR staff into HR managers.

The main regularities are identified, positive, which contribute to the achievement of the goals of the state employment policy, and negative, which hinder their achievement. The authors noted that the trends of the process of reproduction of the system of jobs remain uncertain patterns and trends of reproduction of the system of jobs of domestic enterprises and the economy in general and do not realize reserves to increase employment efficiency by increasing the validity of state policy to create jobs and dissemination of models of economic behavior focused on the expanded intensive reproduction of the workplace system.

It is established that anti-crisis personnel management is an important component of enterprise management and has a significant impact on the efficiency of its economic activity.

Key words: crisis management, accounting information, personnel, agricultural enterprise, workplace, success factors.
\end{abstract}

Вступ. Нові економічні умови становлення ринкового механізму у перехідний період дозволили призвели до того, що значна частина сільськогосподарських підприємств, внаслідок загальноекономічної кризи, виявилися неспроможними в економічному відношенні та постали перед загрозою банкрутства. При низькій 
ефективності підприємницької діяльності, важко говорити про швидкі та позитивні зміни щодо підвищення ефективності використання персоналу, підвищення його якісних характеристик.

Антикризове управління у провідних підприємствах країн із розвинутою ринковою економікою $є$ невід'ємним елементом єдиної системи управління підприємством і являє собою систему заходів, спрямованих не тільки на вихід підприємства 3 кризи, але й запобігання входження в таку ситуацію. Специфіка антикризового управління сільськогосподарських підприємств в Україні полягає у тому, що більшість 3 них мають потребу в антикризовому управлінні одночасно із радикальними та непередбачуваними змінами в економіці країни.

Постановка завдання. Сьогодні госро постає питання необхідності формування ефективної облікової інформації у системі антикризового управління персоналом підприємств. Саме процес винекнення криз на підприємстві та повязані $з$ цим труднощі зумовлюють розробку системи антикризового управління персоналом на підприємстві.

Результати. У системі інформаційного забезпечення антикризового управління облік посідає одне з головних місць. Метою бухгалтерського обліку є забезпечення керівництва підприємства та інших фахівців відповідних структурних підрозділів необхідною, повною, вірогідною, оперативною та достовірною економічною інформацією про господарські процеси, стан та використання ресурсів підприємства, розрахункові взаємовідносини з покупцями, постачальниками, персоналом, бюджетом, результати діяльності та рух грошових коштів для обгрунтованого прийняття поточних та довгострокових управлінських рішень. Формування на підприємстві підрозділу антикризового управління полягає у завчасному формуванні групи, члени якої повинні швидко реагувати на події, передбачати появу небажаних тенденцій, контролювати технічні й економічні наслідки діяльності підприємства. [4].

Група фахівців може бути виділена в окремий підрозділ, який підпорядковується безпосередньо керівникові, або отримати статус консультаційного органу. Критерієм відбору до групи повинні стати такі властивості: досвід практичної діяльності на підприємстві, здатність до аналітичного розуміння, швидка реакція на зміну ситуації, хороша комунікабельність, вміння вирішувати конфліктні ситуації тощо.

На основі досліджень можемо сформулювати такий перелік пріоритетів та завдань антикризового управління персоналом аграрних підприємств (рис.1).

Формування ефективної організаційної структури спричинено відповідною нестабільністю зовнішнього середовища та поступальним розвитком самого підприємства. В умовах жорсткої конкуренції, завершального етапу трансформації економіки та необхідності застосування постулатів антикризового управління важливим $€$ формування організаційної структури, для якої характерною буде стійкість, маневреність, гнучкість, оптимальність, ефективність.

Облікова оцінка потреби в кадрах має проводитися періодично (щомісяця), i полягає в дослідженні внутрішнього кадрового потенціалу, визначенні вакантних посад, формуванні штатних розписів, вирішенні проблем найму і відбору кадрів. Дослідження й оцінка персоналу полягає у розробленні та застосуванні методик аналізу кадрів, їх тестуванні, виявленні професійно-кваліфікаційних характеристик, відповідності професійних навиків окремих працівників їхнім посадам 3 метою збільшення ефективності використання персоналу підприємства. 


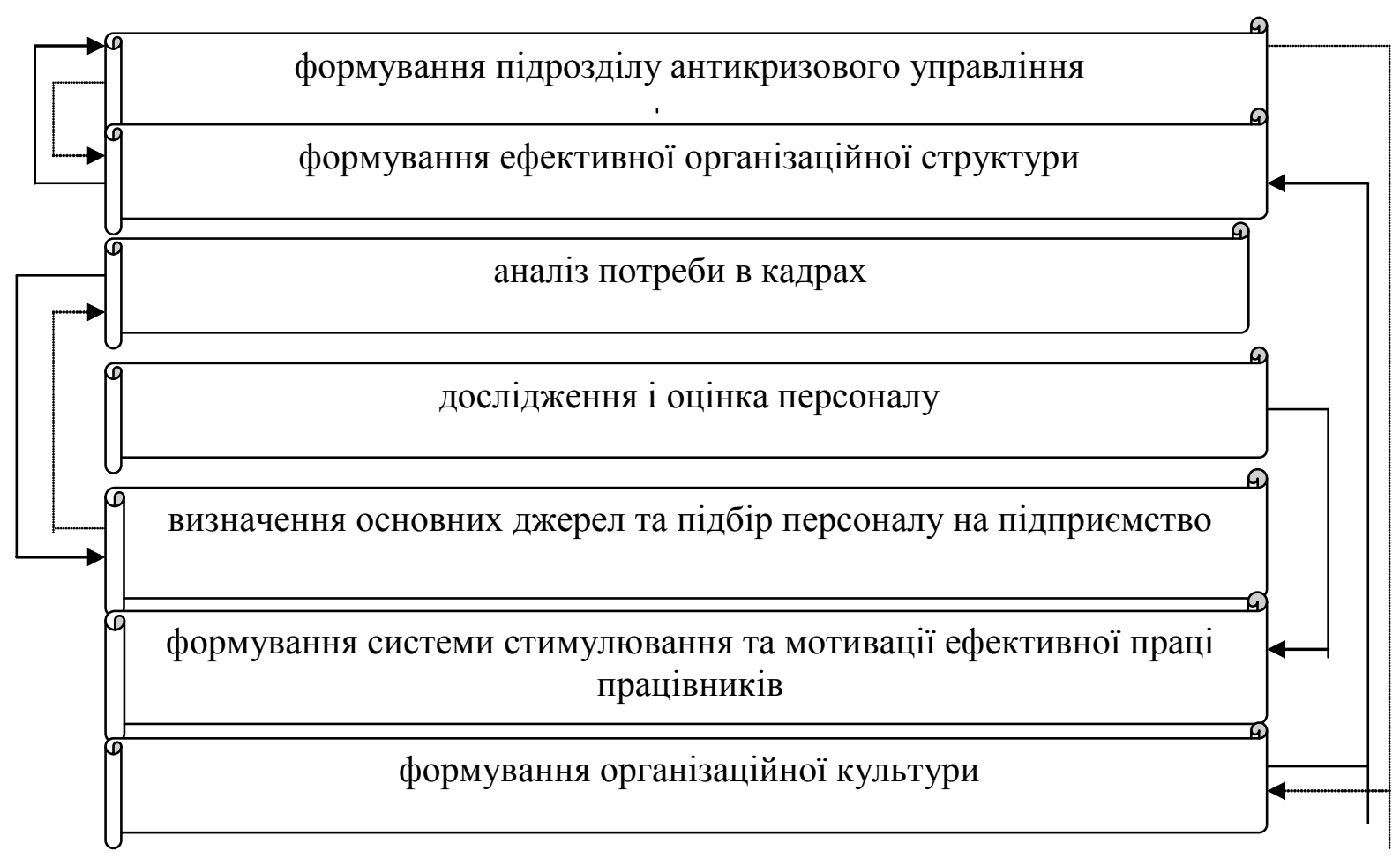

Puc. 1. Пріоритети та завдання антикризового управління персоналом для аграрних підприємств.

Fig. 1. Priorities and tasks of anti-crisis personnel management for agricultural enterprises.

Визначення основних джерел i підбір трудових ресурсів на підприємство передбачає проведення кадрового маркетингу на основі прогнозних даних про потребу в кадрах та комплексу якостей, якими вони повинні володіти. Ефективний пошук та підбір кадрів проводиться такими способами:

- пошуком перспективних студентів, які проходять тестування, випробувальний термін та подальше навчання поєднують із частковою зайнятістю на підприємстві;

- співпрацею із державною службою зайнятості;

- використанням приватних фірм, які надають послуги по підбору і підготовці кадрів певної спеціальності та кваліфікаційного рівня.

Формування системи стимулювання та мотивації ефективної праці працівників. Складність трансформаційного процесу економіки України, високий рівень реального безробіття, низька заробітна плата та систематичні затримки в їі виплаті на більшості підприємств, високий відсоток громадян України, які працюють за іiі межами, дозволяють вважати, що основним стимулом, все-таки, є матеріальний інтерес. Однак, не потрібно відкидати і світовий досвід морального стимулювання, хоча в Україні він не $є$ ключовим. Антикризове управління персоналом передбачає ретельний аналіз існуючої системи мотивації праці та встановлення оптимального рівня оплати праці для ефективного використання персоналу.

Формування організаційної культури поряд із виробничою потужністю, технологією, моральним зношуванням основних виробничих фондів, персоналом $\epsilon$ одним із важливих чинників ефективної діяльності підприємства. Організаційна культура виступає як умовна система, що складається з набору принципів і стандартів, 
що визначають взаємодії й узгодженість членів колективу, управлінської ланки, структурних підрозділів і ключових чинників розвитку підприємства.

Організаційна культура підприємства — це набір специфічних, характерних для конкретного об'єкта формалізованих і неформалізованих правил, сформованих загальними цінностями, місією, оточенням, яким підкоряється і відповідно до яких функціонує все підприємство [5].

Безперечно, організаційна культура $є$ об'єктом вивчення та вдосконалення антикризового управління, але на вітчизняних підприємствах ця проблема перебуває на другому плані, оскільки більш важливими є зменшення плинності кадрів, підбір висококваліфікованих спеціалістів і збільшення ефективності використання персоналу.

Можна ще раз наголосити, що антикризове управління персоналом $є$ важливою складовою управління підприємством і має значний вплив на ефективність його господарської діяльності.

Одним із важливих заходів попередження кризових ситуацій щодо використання персоналу $є$ планомірне здійснення заходів на підприємстві щодо усунення невідповідності між фактичним і необхідним складом персоналу за рівнем освіти та професійної підготовки. Цей елемент, у зв'язку з незадовільним станом використання персоналу, на наш погляд, повинен визначатися як за фахівцями з вищою освітою, так і за висококваліфікованими робітничими кадрами. Такий підхід дозволить, на нашу думку, відображати не тільки додаткову потребу у певній кількості працівників для заміщення нових створюваних робочих місць, але й враховувати потребу підприємства у зміні якісних характеристик персоналу на укомплектованих робочих місцях, що досить важливо в умовах запровадження інноваційно-інвестиційної моделі розвитку економіки.

Так, наприклад, поруч з частковою заміною практиків, може бути передбачено підвищення кваліфікації практиків чи професійна перепідготовка працівників, рівень підготовки яких не відповідає потрібному рівню або профілю освіти, а також планомірне переміщення працівників, які мають потрібний рівень та профіль освіти, але зайняті на робочих місцях, що не відповідають цьому рівню та профілю.

Можна визначити наступні складові додаткової потреби в персоналі для сільськогосподарського підприємства: приріст чисельності працівників у плановому періоді; чисельність працівників, необхідних на заміщення вакантних посад та вільних робочих місць; чисельність необхідних працівників унаслідок призову до лав Збройних Сил України, вибуття жінок у відпустку у зв'язку з вагітністю, пологами і для догляду за дитиною; чисельність тих, хто потрібний на компенсацію вибуття працівників внаслідок природних причин; чисельності тих, хто потрібний на компенсацію вибуття персоналу внаслідок плинності кадрів; чисельності фахівців 3 вищою освітою, які необхідні на часткову заміну практиків на посадах фахівців; чисельності тих, хто потрібний для компенсації працівників у зв'язку з їх вступом до навчальних закладів.

Основні чинники, які впливають на потребу у персоналі можна розділити за формами прояву; за тривалістю дії; за строками можливого використання; за організаційно-господарчими рівнями (рис. 2). 


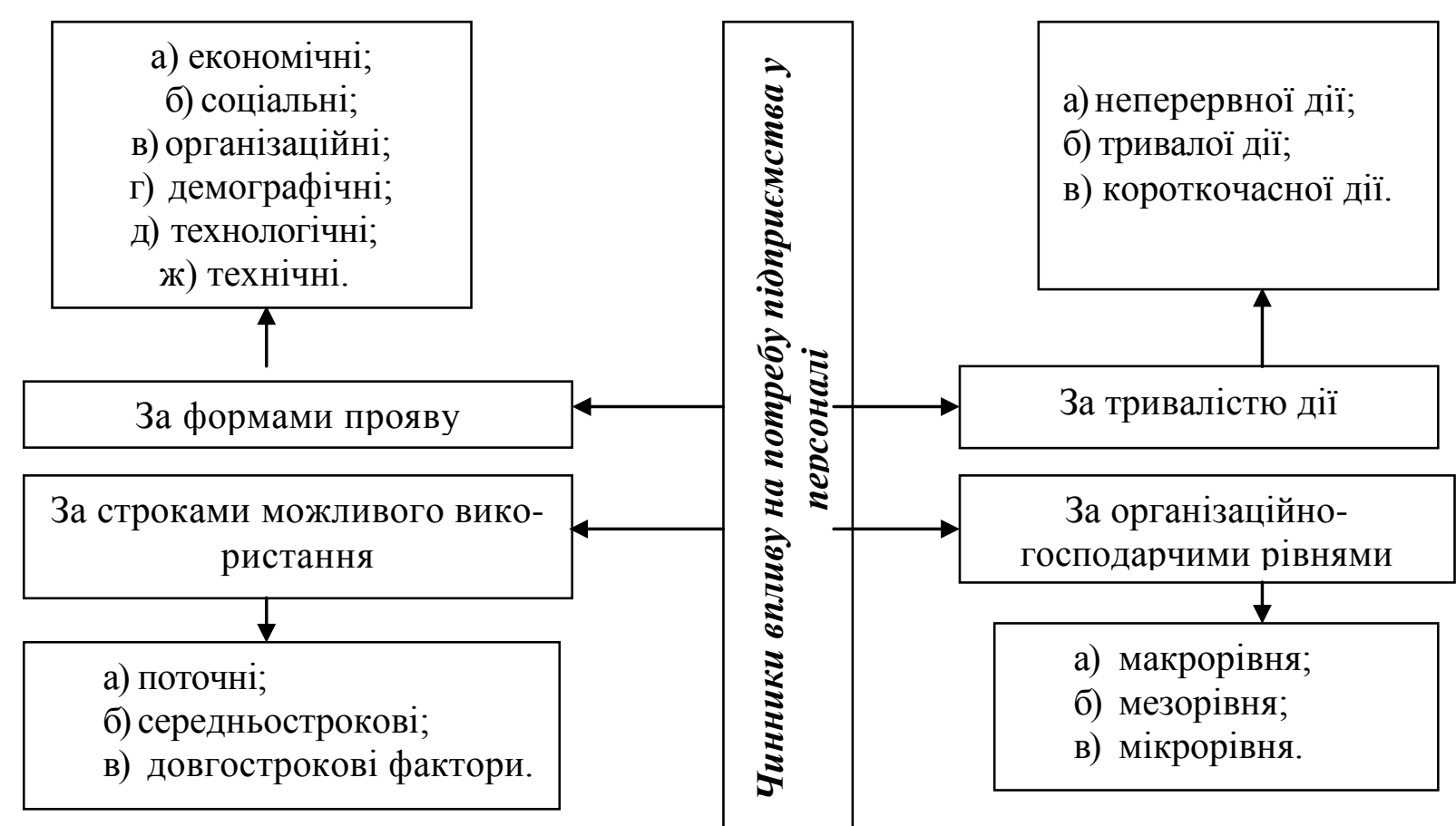

Pис. 2 Чинники, які слід врахувати при визначенні потреби підприємства у персоналі.

Fig. 2. Factors that should to be considered in determining the needs of enterprise staff.

В даний час теорія і практика налічує ряд методів прогнозування і планування потреби в персоналі, однак, кожний із цих методів має свої переваги, недоліки і межі застосування. Одні є універсальними, інші використовуються лише в окремих видах економічної діяльності. Тільки у закордонних країнах для отримання різного типу прогнозів нині використовується близько ста методів. Всі запропоновані на теперішній час методи можна класифікувати за ступенем охоплення причинних зв'язків, динаміки процесів, за використанням математичного інструментарію та за часовим лагом родом прогнозування (табл. 1).

Аналіз методів обчислення, які використовуються, дозволяє зробити висновок про те, що кожен 3 них, поряд 3 позитивними сторонами, має ряд недоліків, неповною мірою враховує характер змін кількості персоналу під впливом цілої низки нормативно-правових економіко-організаційних та науково-технічних факторів, які визначають перспективу розвитку відповідного виду економічної діяльності.

Підвищення обгрунтованості прогнозування і планування потреби в персоналі викликає необхідність використання комплексного системного підходу, який грунтується на виявленні впливу низки факторів розвитку окремого виду економічної діяльності на перспективну чисельність робітників та фахівців з вищою освітою. Тому ми поділяємо точку зору тих дослідників, які стоять на позиції комплексного підходу в плануванні та прогнозуванні потреби в персоналі, що дозволяє досягти оптимальної збалансованості ресурсів праці з потребами в персоналі [4].

Вибір конкретного методу i способу розрахунку залежить від ступеню підготовленості працівників служб управління персоналом підприємств, зайнятих плануванням потреби у персоналі, характеру розв'язуваних завдань і надійності інформаційного забезпечення менеджменту персоналу. 
Таблиия 1

Методи визначення прогнозованої потреби у персоналі в залежності від тривалості періоду

Table 1

Methods for determining the projected need for staff depending on the length of the period

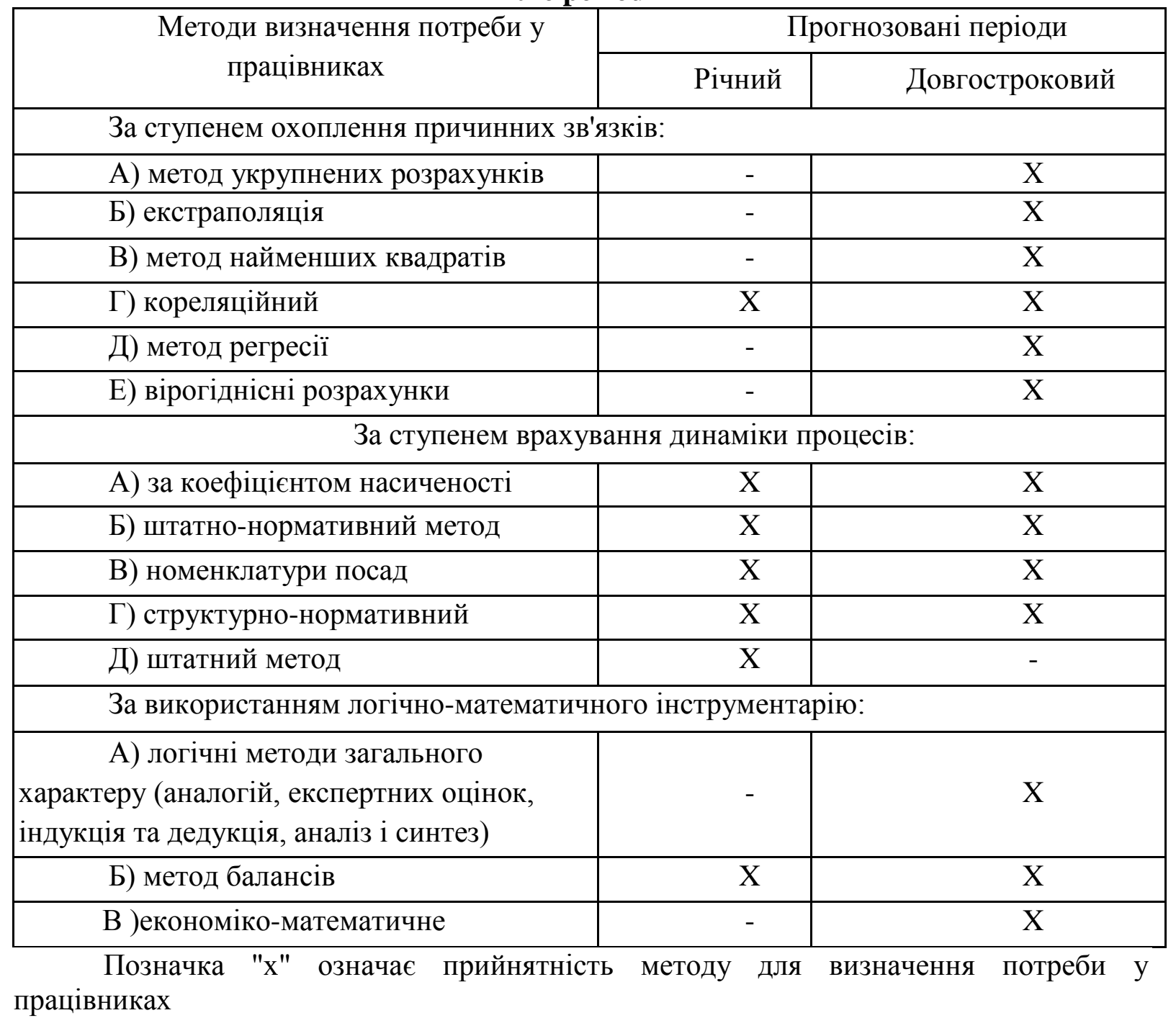

Діяльність будь-якого суб'єкта господарювання, як правило, спрямована не тільки на його поточне функціонування, але й на перспективу. Саме з огляду на неї розробляється стратегія подальшого розвитку. Особливо велику роль відіграє стратегічне планування в сучасних нестабільних умовах господарювання, спричинених переходом економіки України до ринкових відносин, які передбачають, що кожен суб'єкт підприємницької діяльності сам відповідає за прийняті рішення. Тому велика увага приділяється правильності вибору іiї перспективних напрямів, одним із яких може бути “відтворення системи робочих місць” (рис 3). 


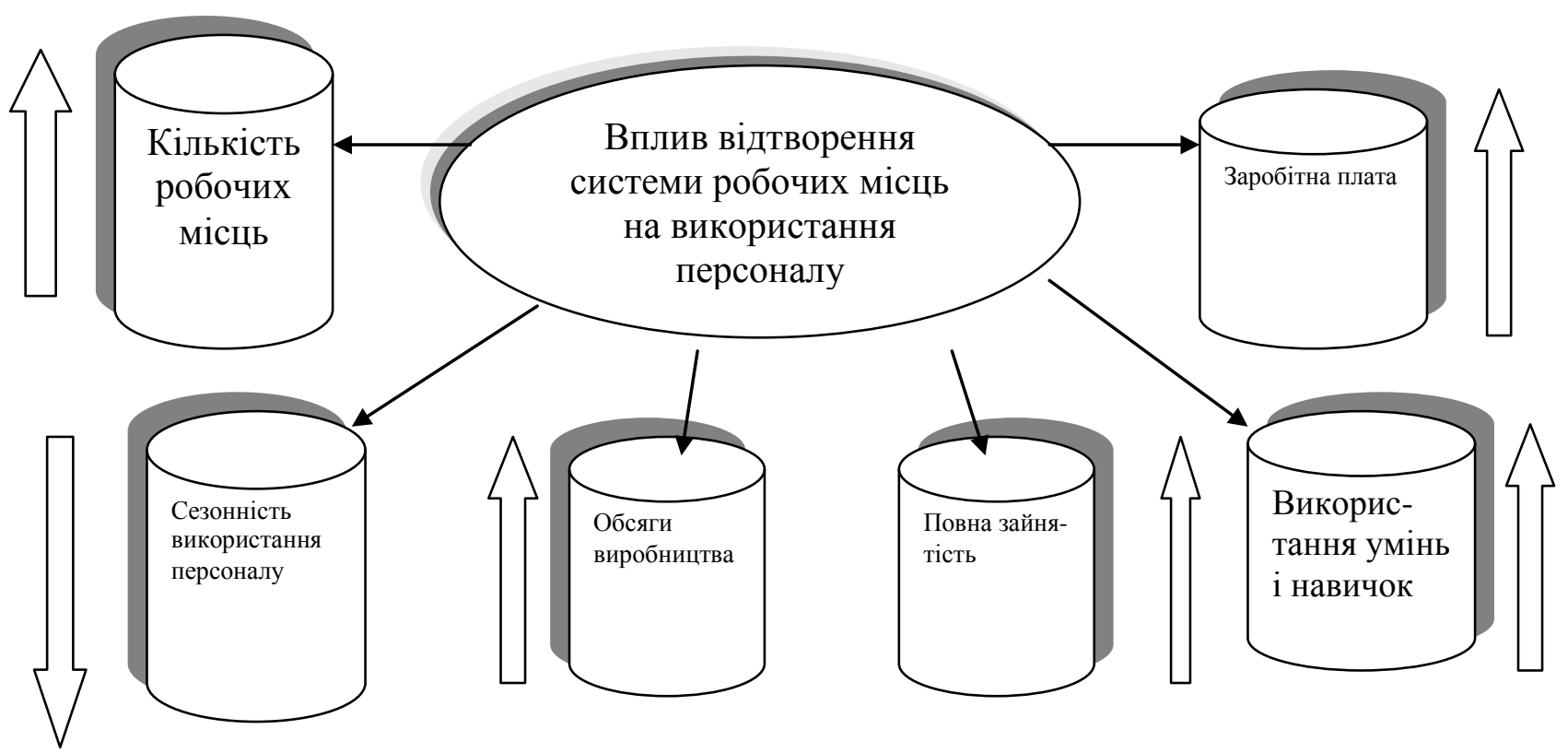

Puc. 3. Схема впливу відтворення системи робочих місць на ефективність використання персоналу

Fig. 3. The scheme of influence of reproduction of system of workplaces on efficiency of use of the personnel

Процеси відтворення системи робочих місць визначають масштаби та організаційно-технічні параметри сфери докладання праці, відповідно, визначають потенціал економіки щодо забезпечення зайнятості населення. Масштаби системи робочих місць на макроекономічному рівні виступають визначальним чинником повноти зайнятості, а структура робочих місць втілює власне виробничі чинники іiі ефективності і раціональності. Відповідно, будь-яка політика зайнятості має грунтуватись на розумінні закономірностей відтворення системи робочих місць всіх рівнів (від підприємства до національної економіки), на моделюванні залежностей, що опосередковують зв'язки між процесами створення (виведення) робочих місць, змінами параметрів їх використання і рівнем повноти та ефективності зайнятості.

Для визначення цілей та важелів державної політики зайнятості щодо сприяння створенню та поліпшенню структури робочих місць необхідно визначити головні закономірності, позитивні (такі, що сприяють досягненню цілей державної політики зайнятості) і негативні (такі, що перешкоджають їх досягненню) тенденції процесів відтворення системи робочих місць залишаються невизначеними закономірності і тенденції відтворення системи робочих місць вітчизняних підприємств та економіки загалом та не реалізуються резерви підвищення ефективності зайнятості за рахунок підвищення обгрунтованості державної політики сприяння створенню робочих місць та поширення моделей господарської поведінки, орієнтованих на розширене інтенсивне відтворення системи робочих місць

На тих підприємствах, де розширення масштабів сфери докладання праці супроводжується збільшенням резервів зростання чисельності за рахунок усунення простоїв обладнання і устаткування робочих місць протягом зміни формується екстенсивний тип розширеного відтворення системи робочих місць - чисельність 
зайнятих та кількість фізичних робочих місць на підприємствах зростає без використання наявних резервів розширення сфери докладання праці на існуючих фізичних робочих місцях, за рахунок покращення їх завантаження протягом зміни. Відповідно в процесі розширення сфери докладання праці показники використання робочих місць за часом не покращуються, а погіршуються. Такий тип відтворення свідчить про формування на підприємстві і паралельне функціонування двох секторів робочих місць - застарілого із низькою ефективністю використання наявних фізичних робочих місць для розширення сфери докладання праці і нового, де забезпечується кращий рівень використання наявних фізичних робочих місць для розширення сфери докладання праці. Таким чином, сектор застарілих робочих місць виконує подвійну функцію - забезпечення бажаного рівня виробничої потужності підприємства (хоча і знижують середній рівень ефективності праці) і утримання надлишкової чисельності персоналу, динаміка якої не відповідає зміні питомої технологічної трудомісткості продукції та динаміці їі обсягів [2].

Для сільського господарства, яке несправедливо займає останні місця у питаннях впровадження прогресивних форм організації праці та управління виробничим процесом, адаптація сучасного досвіду менеджменту, і особливо для управління людьми, сьогодні є вкрай необхідним і актуальним. Одним із таких нових підходів $є$ перетворення працівників відділів кадрів на менеджерів по управлінню людськими ресурсами - HR-менеджерами.

HR-менеджер (від англ. human - людський i resource - pecypc) в умовах сучасного ринку праці - доволі непроста фігура в складній рольовій грі жорстокого ринку. Кадровик учора й менеджер сьогодні - це дві різні особистості, це дві різні епохи. Нині управління людськими ресурсами - головна функція будь-якої організації. HR-фахівці повинні гнучко й актуально враховувати у своїй роботі миттєві зміни в політиці підприємства - від технократичного підходу до визначення майбутніх потреб людей і розвитку їхнього потенціалу.

Здавалося б, сучасний ринок випускників вищих навчальних закладів дає достатню кількість молодих фахівців. Проте власнику сільськогосподарського підприємства дуже важливо не помилитися у виборі, який далекий від професійного підбору працівників і наймі менеджера якраз для забезпечення підприємства кадрами. Важливо застрахуватися від HR-«фахівця», який ледь опанував теоретичну основу своєї майбутньої професії i, крім умовно-поверхневого знання кількох імен і назв методик, передусім, не знає, як побудувати стосунки із своїми близькими, рідними, колегами тощо. Чи не зашкодить такий фахівець? Адже майстерність маневрувати у вирі людських емоцій можна впевнено назвати вродженою компонентою і впливом виховання сім'ї та першого соціального оточення.

Отож, варто врахувати та прорахувати інвестиційну доцільність “роздування" штату фахівців із роботи 3 персоналом. Щоб обіймати посаду фахівця у сфері управління людським ресурсами, варто також мати досвід роботи, а для управлінських посад, посад трудових арбітрів і спеціалістів з примирення сторін це є обов'язковою вимогою. Тому багато хто 3 роботодавців при заміщенні посад у сфері управління персоналом надають перевагу тим кандидатам, які під час навчання у вузах пройшли стажування або практику на відповідних посадах.

До початку роботи слід вирішити такі питання: - що конкретно повинен робити HR-фахівець; - якими компетенціями та повноваженнями управлінець готовий поділитися 3 ним; - чи HR-фахівець буде “буфером та громовідводом” від вічних запитань, проблем, незадоволень зарплатою від працівників, чи він буде "адаптером" планування, організації, впровадження кадрової, мотиваційної політики. Після того як управлінець з'ясував параметри функціонального навантаження потенційного 
Актуальні проблеми розвитку економіки регіону. Вип 16. T.2

спеціаліста, слід врахувати загальну кількість персоналу та тенденції до змін у колективі: як кількісні, так і якісні. Вважається, що для одного HR-фахівця оптимальним $є$ підприємство зі штатом до 130 осіб штатних одиниць. При ритмічно організованій роботі та ефективному використанні часу HR-фахівець встигає якісно виконати свою роботу [5].

Основними проблемами, які супроводжують появу HR-менеджера є:

$\checkmark$ конфлікт інвестицій в HR-відділ та виробництво чи інший основний вид діяльності компанії: HR-фахівці переконують керівників у необхідності вкладання коштів у навчання персоналу, в той час, коли пріоритетним для компанії прийнято вважати інвестиції в обладнання чи нерухомість;

$\checkmark$ конфлікт інтересів: замість того, щоб докласти зусиль і віднайти компроміс подолати напругу та усунути спротив колективу, HR-фахівці часто перевтілюються в імпровізованих представників профспілки та відстоюють позицію працівників;

$\checkmark$ нерідко виникає проблема у сприйнятті HR-фахівця персоналом, оскільки молодим HR-менеджерам доводиться працювати з різними віковими категоріями працівників, а подекуди набагато старшими від них.

У зв'язку із цим, для ефективної організації роботи HR-менеджера на підприємстві слід провести низку заходів, а саме: перевірити рекомендаційні листи та автобіографічну інформацію HR-фахівця, звернувши увагу на сімейний стан та громадську активність; акцентувати увагу HR-фахівця на тому, що управління персоналом - це поєднання мистецтва та точної науки; залучити HR-фахівця до формування річного бюджету на навчання та розвиток персоналу.

Крім цього слід відмітити, що вводячи посаду HR-фахівця і приймаючи на неї конкретну людину важливо, щоб вона відповідала особливим вимогам (puc. 4).

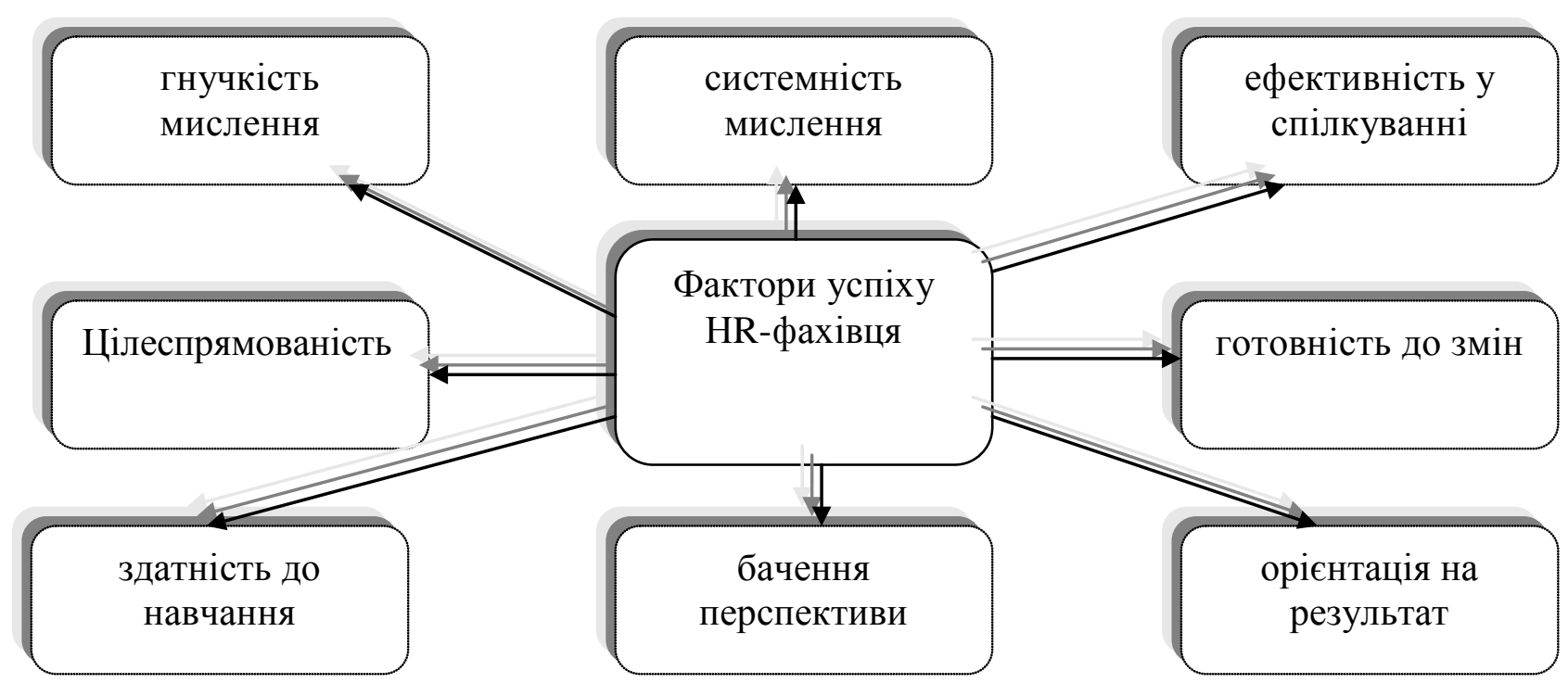

Puc. 4. Фактори успіху HR-фахівця.

Fig. 4. Success factors of HP-specialist.

Фахівці з управління людськими ресурсами повинні вміти: працювати з людьми, які мають різний рівень культури, освіти, різний життєвий та професійний досвід; діяти рішуче, неупереджено й справедливо; вміти переконувати людей; діяти за умов психологічного тиску.

Слід пам'ятати, що беручи на роботу HR-менеджера, керівник звільняє себе від необхідності витрачати час на підбір персоналу. Звичайно, іноді виникає думка, що керівник підприємства сам міг би знайти кращого працівника без HR-менеджера, щоб 
заповнити відкриту вакансію, оскільки ліпше ознайомлений і з іï специфікою та кваліфікаційними вимогами. Проте HR-менеджер - це особа, відповідальна не лише за підбір персоналу, а й за його навчання та оцінку. Отже, наймаючи його, керівник може цілком приділити увагу стратегії своєї компанії.

Висновки. Підвищення ефективності управління персоналом продиктований вимогами сучасності як інформаційне забезпечення управління персоналом. Дієве антикризове управління спирається на облікову інформацію, зміст якої та терміни подання залежать від стадії кризової ситуації, в якій знаходиться підприємство. Сучасному зовнішньому середовищу, в якому працюють вітчизняні підприємства, властивий високий динамізм. Процеси ринкової трансформації в Україні та підвищення конкуренції викликають необхідність швидкого та гнучкого реагування підприємств на зміни у ринковому середовищі. За таких умов традиційні системи управління виробництвом не забезпечують адекватного реагування і вимагають використання сучасних концепцій, методів та інструментів управління підприємством, а також інформаційних технологій, технічних засобів та програмного забезпечення. В цьому аспекті набувають актуальності проблеми якісного інформаційного забезпечення управління підприємством і усіма його складовими, особливо персоналом.

1. Андрійчук В.Г. Теоретико-методологічне обгрунтування ефективності виробництва // Економіка АПК. 2005. С. 53-63.

2. Верба Д. В., Терещенко О. В. Відтворення системи робочих місць як чинник масштабів сфери докладання праці на промислових підприємствах м. Києва. Економіка та держава. №5. 2007. С. $77-84$.

3. Гавриленко В.О. Облікова інформація у системі антикризового управління. Глобальні та національні проблеми економіки. 2017. Вип. 20. С 946-949. http://global-national.in.ua/archive/202017/191.pdf (дата звернення: 15.10.2020)

4. Криклій А. С. Формування та планування додаткової потреби в персоналі: методологічні та практичні аспекти. Економіка та держава. №4. 2005. С. 61-64.

5. Лігоненко Л. О. Антикризове управління підприємством: теоретико методологічні засади та практичний інструментарій. К.: Київ. нац. торг. екон. ун-т, 2001. 580 с.

6. Малецька О. І. Облік персоналу підприємств: методичні основи дослідження процесу формування та використання. Демократичне управління. 2013. Вип. 12. http://nbuv.gov.ua/UJRN/DeVr_2013_12_35.

7. Нагірний M. Створення HR-відділу на підприємств. Практика управління. №4 (4). 2007. С.1011.

8. Персонал сільськогосподарських підприємств: формування і використання / Біттер О.А., Малецька О.I, Лопушняк Г.С. та ін.. Львів, 2011. 191с.

9. Штангрет А. М. Антикризове управління підприємством: підручник. Львів: Українська академія друкарства, 2008. 396 с.

10. Штангрет А. М., Копилюк О.І. Антикризове управління підприємством: навч. пособ. К.: Знання, 2007. 335 с.

1. Andriychuk, V.G. "Theoretical and methodological substantiation of production efficiency." Economics of agro-industrial complex, 2005, pp. 53-63.

2. Verba, D.V., and O.V. Tereshchenko. "Reproduction of the system of jobs as a factor in the scale of the scope of employment at industrial enterprises of Kyiv.” Economy and State, no.5, 2007, pp. 77-84.

3. Gavrilenko, V.O. "Accounting information in the system of crisis management.” Global and national economic problems, issue 20, 2017, pp. 946-949, global-national.in.ua/archive/20-2017/191.pdf. Accessed 15 Oct.2020.

4. Krykliy, A.S. "Formation and planning of additional staffing needs: methodological and practical aspects.” Economy and State, no.4, 2005, pp. 61-64.

5. Ligonenko, L.O. Anti-crisis management of the enterprise: theoretical and methodological principles and practical tools. Kyiv, Kyiv. nat. auction. econ. University, 2001.

6. Maletska, O.I. "Accounting of personnel of enterprises: methodical bases of research of process of formation and use/" Democratic governance, issue 12, 2013. Vernadsky National Library, nbuv.gov.ua/UJRN/DeVr_2013_12_35. Accessed 15 Oct.2020. 
Актуальні проблеми розвитку економіки регіону. Вип 16. T.2

7. Nagirny, M. “Creation of HR-department at the enterprise.” Management practice, no.4 (4), 2007, pp.10-11.

8. Buriak, O.A., Maletska, O.I., Lopushnyak, G.S. etc. Personnel of agricultural enterprises: formation and use. Lviv, 2011.

9. Stangret, A.M. Anti-crisis management of the enterprise: Textbook. Lviv: Ukrainian Academy of Printing, 2008.

10. Shtangret, A.M., and O.I. Kopylyuk. Anti-crisis management of the enterprise: Textbook. Kyiv, Knowledge, 2007.

УДК 338.48

doi: 10.15330/apred.2.16.210-220

Іванів С. І. ${ }^{1}$, Драбчук Н. Ю. ${ }^{2}$

ВПРОВАДЖЕННЯ СІЛЬСЬКОГО ЗЕЛЕНОГО ТУРИЗМУ У ФЕРМЕРСЬКИХ

ГОСПОДАРСТВАХ ЯК ОДИН ІЗ НАПРЯМКІВ ЕФЕКТИВНОГО ВИКОРИСТАННЯ ЇХ РЕСУРСНОГО ПОТЕНЦАЛУ

\author{
Державний вищий навчальний заклад \\ «Прикарпатський національний університет \\ імені Василя Стефаника», \\ кафедра обліку і аудиту, \\ вул. Шевченка, 57, м. Івано-Франківськ, \\ 76000 , Україна, \\ ${ }^{1}$ тел. +(380)999178583, \\ e-mail: feya8246@ukr.net, \\ 2 тел. +(380)957624145, \\ e-mail: Natalya_mazuryk@ukr.net
}

\begin{abstract}
Анотація. Стаття присвячена розгляду питань щодо можливості отримання фермерськими господарствами додаткового доходу шляхом впровадження сільського зеленого туризму.

Метою дослідження є вивчення особливостей впровадження сільського зеленого туризму в фермерських господарствах на території України, зокрема особливості, переваги та стримуючі фактори розвитку.

При проведенні дослідження були використані такі методи: графічний для відображення розвитку агротуризму в ОТГ; абстрактно-логічний для визначення сутності поняття «сільський зелений туризм» та «агрокластер»; аналіз - для формування особливостей розвитку сільського зеленого туризму в Україні; групування для визначення основних чинників, що сповільнюють розвиток агротуризму в українських селах; узагальнення, який був використаний для формування висновків, проведеного дослідження.

У статті обгрунтовано важливість провадження додаткової діяльності фермерами у вигляді агротуризму та відображено основні переваги такої діяльності. Досліджено стримуючі чинники, які мають місце в розвитку агротуристичної діяльності в Україні. Здійснено аналіз розвитку сільського зеленого туризму в іноземних країнах. Виокремлено напрямки розвитку агротуризму в ОТГ. Описано вплив кластерної системи на економічне становище сільських місцевостей та причини повільного розвитку.

Наукова новизна проведеного дослідження полягає у формуванні авторами структурованої послідовності дій при впровадженні додаткової діяльності у вигляді агротуризму; формуванні визначення поняття «агрокластер».

Результати, які отримані в процесі дослідження, можуть бути використані фермерськими господарствами, сільськогосподарськими підприємствами, особистими селянськими господарствами для реалізації агротуристичної діяльності в своєму регіоні.
\end{abstract}

